\title{
Emergency Surgical Treatment in Primary Cerebral Hydatid Cyst: A Case Report and Review of the Literature
}

\author{
Alp Karaaslan, ${ }^{1}$ Ali Börekci, ${ }^{2}$
}

$$
\begin{array}{r}
\text { 'Department of Neurosurgery, } \\
\text { T.C. S.B., Esenyurt State Hospital, } \\
\text { İstanbul, Turkey } \\
\text { 2Department of Neurosurgery, } \\
\text { T.C. S.B. SBÜ, Fatih Sultan Mehmet } \\
\text { Training and Research Hospital, } \\
\text { İstanbul, Turkey }
\end{array}
$$

\begin{abstract}
Hydatid cyst accounts for $3 \%$ to $4 \%$ of all intracranial lesions. The initial diagnosis is typically based on clinical suspicion, usually with a patient history of having traveled to a region where it is endemic or living in contact with cattle or dogs, and the diagnosis is confirmed with serological tests and imaging. Emergent surgery for cerebral hydatid cyst without first obtaining magnetic resonance image has also been reported in the literature. Presently described is a case of a 22-year-old patient who presented with symptoms of intracranial pressure and neurological deterioration diagnosed as primary cerebral hydatid cyst, and a review of the literature.
\end{abstract}

\section{INTRODUCTION}

Hydatid cyst disease is endemic in the Middle East, Turkey, South America, Southern Europe, New Zealand, and Australia. ${ }^{[]]}$In human beings, hydatid cyst disease is most frequently caused by Echinococcus granulosus larvae. The small intestine of cattle, goats, and sheep is usually the intermediate host of the parasite, and wolves and dogs often become the final hosts. Human beings can be incidental intermediate hosts of Echinococci. ${ }^{[2]}$ Following the intake of contaminated foods, embryos can migrate to the liver and lungs through the portal system. ${ }^{[3]}$ The liver is the organ primarily affected by the disease.

Intracranial hydatid cyst is rarely seen; it has been reported in $1 \%$ to $2 \%$ of all cases with hydatid cyst disease. ${ }^{[4]}$ It is more frequently seen in the pediatric population, and lesions are generally distributed in the supratentorial and middle cerebral perfusion areas. The essential treatment is to extract the cyst en bloc without rupturing it. The most often used surgical technique is Dowling's technique, as modified by Arana-Iniguez..$^{\left[{ }^{[}\right]}$In this paper, a case of a 22-year-old patient with primary, cerebral hydatid cyst who presented with intracranial pressure and sudden neurological worsening and who was underwent emergency surgery is discussed in the light of the literature.

\section{CASE REPORT}

A 22-year-old patient, who had immigrated to our country from Syria, presented at the intensive care unit with symptoms of headache, vomiting, and nausea persisting for the previous month, and a tendency to fall asleep (Glasgow Coma Scale [GCS] score: 14) for the last 2 days. Based on information obtained from his friends, he was earning a liv- 

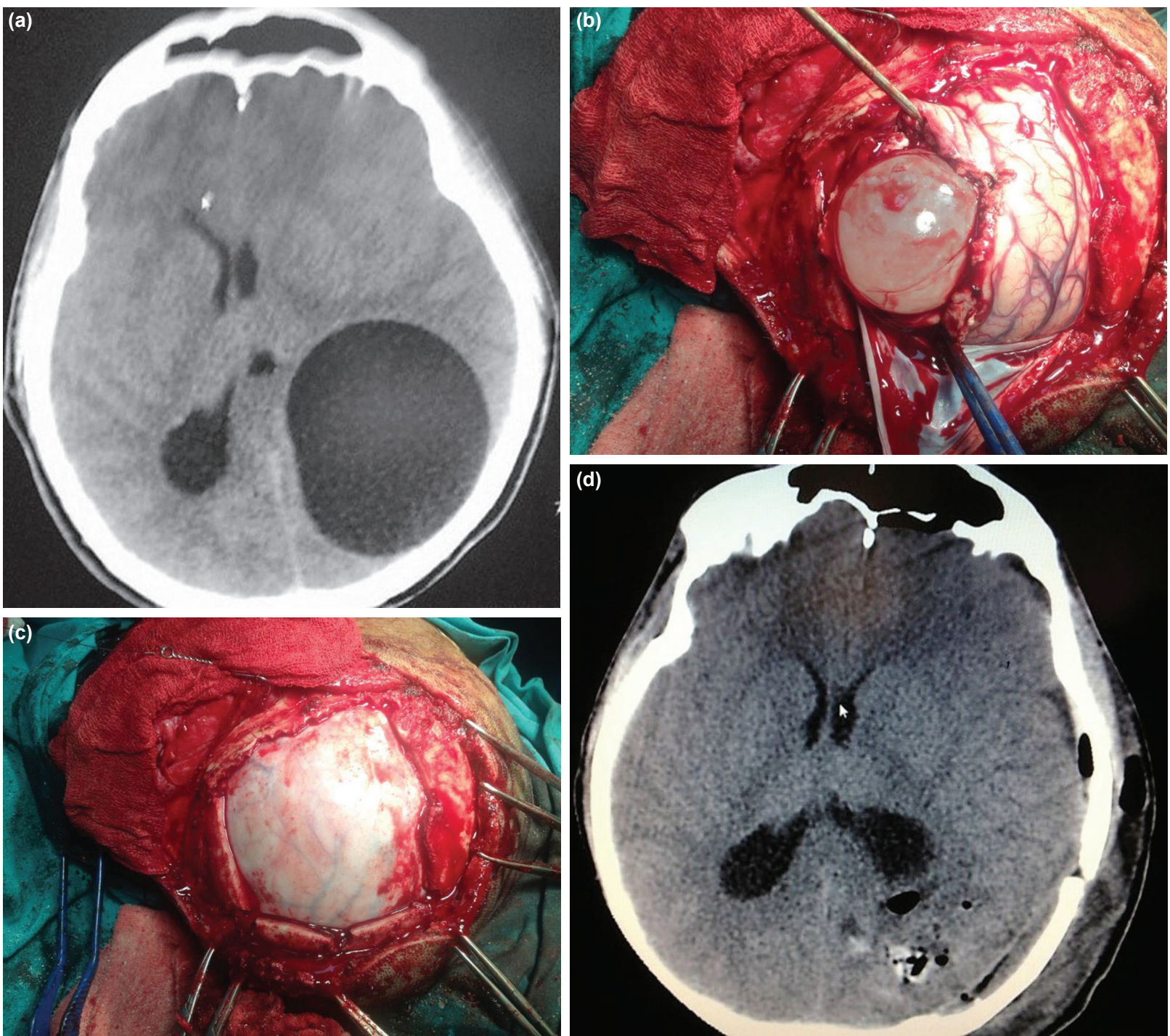

Figure 1. (a) Left parieto-occipital cystic mass. (b) Extended craniotomy performed according to Dowling's method. (c) Enucleation of the cyst without rupture. (d) Postoperative cerebral computed tomogram.

ing in animal husbandry. His physical examination revealed a moderately good general state of health, somnolence, poor cooperation, and right-sided hemiparesis (global 4/5). Routine laboratory test results were within the normal range, and a chest X-ray was unremarkable. Cranial computed tomography (CT) detected a round, hypodense cystic mass $8 \times 6 \mathrm{~cm}$ in size, with smooth, regular contours and a midline shift localized in the left parieto-occipital region. (Figure Ia). Cranial magnetic resonance imaging (MRI) was scheduled for the patient with a presumed diagnosis of intracranial hydatid cyst, and an urgent operation was performed as a result of a sudden worsening of his clinical state and a dramatic regression of his GCS to 8 (Best eye response: I, best verbal response: 2, best motor response: 5 ).

The hydatid cyst was enucleated without rupture using Dowling's method through an extended left parietal-oc- cipital craniotomy incision (Figures Ib and c). The surgical site was irrigated with hypertonic sodium chloride, and a postoperative control cerebral CT demonstrated complete removal of the cyst and correction of midline shift (Figure Id). Diagnosis of hydatid cyst was confirmed based on histopathological analysis. Postoperatively, the patient's deficits were relieved, and tests performed during hospitalization did not reveal presence of hydatid cyst in another organ, so he was discharged with a prescription for medical treatment (albendazole, 10-15 mg/kg/day).

\section{DISCUSSION}

In this report, a 22-year-old patient with a primary cerebral hydatid cyst in the left parietal-occipital region who presented with intracranial pressure and who went urgent surgery as a result of sudden neurological worsening is 
Table I. Some of the cases in the literature with urgent operation for indication of intracranial hydatid cyst

\begin{tabular}{lclll}
\hline Author & $\begin{array}{c}\text { Age range } \\
\text { (years) }\end{array}$ & Symptom & Surgery & Localization \\
\hline Wani et al. ${ }^{[7]}$ & $8-13$ & Worsening neurological state & Dowling's technique & Supratentorial \\
Duransoy et al. ${ }^{[5]}$ & 13 & Midbrain herniation & Dowling's technique & Right temporoparietal \\
Hajhouji et al. ${ }^{[23]}$ & 7 & Epileptic episode & Dowling's technique & Right parietal \\
Önal et al. ${ }^{[8]}$ & 13 & Worsening neurological state & Dowling's technique & Supratentorial \\
Cavuşoğlu et al. ${ }^{\left[{ }^{[3]}\right.}$ & 15 & Worsening neurological state & Dowling's technique & Right parieto-occipital \\
Karakoc et al. ${ }^{[24]}$ & 14 & Respiratory distress and quadriparesia & Microsurgical technique & Posterior fossa \\
Saqui et al. ${ }^{[13]}$ & 12 & Symptoms of increased intracranial pressure & Cyst aspiration & Posterior fossa \\
Touzani et al. ${ }^{[10]}$ & 5 & Midbrain herniation & Dowling's technique & Left frontoparietal \\
Said et al. ${ }^{[1]}$ & 20 & Worsening neurological state & Cyst aspiration & Multiple and bilateral \\
Chatzidakis et al. ${ }^{[12]}$ & 27 & Worsening neurological state & Dowling's technique & Left occipital
\end{tabular}

discussed. The cyst was enucleated without rupture using Dowling's technique, and the patient was ultimately discharged with a prescription for medical treatment. Intracranial hydatid cyst is most often observed in the parietal lobes, where blood flow is increased. ${ }^{[5]}$ Hydatid cysts have been reported to enlarge 1.5 to $10 \mathrm{~cm}$ annually. ${ }^{[5]}$ These patients generally present with symptoms of increased intracranial pressure due to the mass effect of a large cyst. Hemiparesis, visual impairment, ataxia, epilepsy, and focal neurological deficits have been reported, depending on the location of the cyst. ${ }^{[6]}$

Wani et al. reported on 5 pediatric patients with supratentorial hydatid cyst aged between 8 and 13 years on whom they had performed emergency surgery because of neurological worsening. ${ }^{[7]}$ Emergency surgery for intracranial hydatid cyst was reported in 7 cases in which it was supratentorial| ${ }^{[7-13]}$ and 2 in which it was infratentoria ${ }^{[14,15]}$ (Table I). These cases were notable because they consist of 7 pediatric and 2 adult patients; the present case was also an adult patient.

Detection of anti-Echinococcus immunoglobulin G antibodies using an enzyme-linked immunosorbent assay test is the definitive laboratory diagnosis of hydatid cyst disease; however, in cases with an isolated cerebral hydatid cyst, antibody titers are generally either very low or undetectable. ${ }^{[16]}$ On cerebral CT, cyst fluid is isodense with cerebrospinal fluid (CSF), and most cysts are round in shape. It is unusual to see perilesional edema or contrast uptake in hydatid cysts as otherwise observed in cystic tumors. ${ }^{[17]}$ On MRI, cyst fluid is isointense with CSF in TI- and T2-weighted images, and in the presence of inflammatory reaction, contrast uptake and peripheral edema may be observed. ${ }^{[18]}$ Cyst wall calcification is seen in nearly $1 \%$ of cysts. ${ }^{[6]}$ In the differential diagnosis, arachnoid cyst, cystic tumor, abscess, and porencephalic cyst should be considered. ${ }^{[6]}$
For a symptomatic hydatid cyst, surgery is the optimal treatment. The goal of the surgery is to extract the cyst without rupturing it in order to prevent recurrence or anaphylactic reaction. ${ }^{[19]}$ The most commonly used surgical technique is Dowling's hydrodissection technique, as modified by Arana-Iniguez. ${ }^{[5]}$ If the cyst ruptures in the surgical field, it should be aspirated immediately, and if any communication between the cyst and the ventricular system does not exist, irrigation of the cystic cavity with hypertonic sodium chloride is recommended. ${ }^{[20]}$ Bakhsh et al. reported the first case of a pineal hydatid cyst presenting with Parinaud syndrome and associated with increased intracranial pressure. The cyst was accidentally ruptured because of an ambiguous preoperative diagnosis; diagnosis was ultimately made based on histopathology. Fortunately, the ruptured cyst did not cause anaphylactic shock, but spread through the intracranial structures. ${ }^{[21]}$

Medical treatment should generally be maintained for at least 6 months. Albendazole may be administered in 2 doses totaling $10-15 \mathrm{mg} / \mathrm{kg} /$ day. ${ }^{[22]}$

\section{Conclusion}

Though cerebral hydatid cysts are slow-growing lesions, they can lead to serious morbidity and mortality in symptomatic cases. In the literature, the requirement for emergency surgery has most often been reported in pediatric cases, but it may be seen also in adult cases.

\section{Informed Consent}

Approval was obtained from the patient.

Peer-review

Internally peer-reviewed.

Authorship Contributions

Surgical and Medical Practices: A.K., A.B.; Concept: A.K., A.B.; Design: A.K., A.B.; Data collection \&/or processing: 
A.K., A.B.; Analysis and/or interpretation: A.K., A.B.; Literature search: A.K., A.B.; Writing: A.K., A.B.; Critical review: A.K., A.B.

\section{Conflict of Interest}

None declared.

\section{REFERENCES}

1. Tüzün M, Hekimoğlu B. Hydatid disease of the CNS: imaging features. AJR Am J Roentgenol 1998;171:1497-500. [CrossRef]

2. Kılınç N, Uzunlar AK, Özaydın M. Seyrek yerleşimli ekinokokozis olguları (45 olgu). Türkiye Ekopatoloji Dergisi 2003;9:25-30.

3. Izci Y, Tüzün Y, Seçer HI, Gönül E. Cerebral hydatid cysts: technique and pitfalls of surgical management. Neurosurg Focus 2008;24:E15.

4. Altinörs N, Bavbek M, Caner HH, Erdogan B. Central nervous system hydatidosis in Turkey: a cooperative study and literature survey analysis of 458 cases. J Neurosurg 2000;93:1-8. [CrossRef]

5. Duransoy YK, Mete M, Barutçuoğlu M, Unsal UÜ, Selçuki M. Intracranial hydatid cyst is a rare cause of midbrain herniation: A case report and literature review. J Pediatr Neurosci 2013;8:224-7.

6. Basarslan SK, Gocmez C, Kamasak K, Ceviz A. The Gigant primary cerebral hydatid cyst with no marked manifestation: a case report and review of literature. Eur Rev Med Pharmacol Sci 2015;19:1327-9.

7. Wani NA, Kousar TL, Gojwari T, Robbani I, Singh M, Ramzan A, et al. Computed tomography findings in cerebral hydatid disease. Turk Neurosurg 2011;21:347-51. [CrossRef]

8. Onal C, Barlas O, Orakdögen M, Hepgül K, Izgi N, Unal F. Three unusual cases of intracranial hydatid cyst in the pediatric age group. Pediatr Neurosurg 1997;26:208-13. [CrossRef]

9. Cavuşoğlu H, Tuncer C, Ozdilmaç A, Aydin Y. Multiple intracranial hydatid cysts in a boy. Turk Neurosurg 2009;19:203-7.

10. Touzani S, Bechri B, Joulali T, Berdai MA, Labib S, Harandou M. Intracerebral hydatid cyst: A rare cause of neurosurgical emergency. Int J Case Rep Images 2016;7:758-61. [CrossRef]

11. Said H, Mohamed M, Mohamed H, Abdenbi EK, Abdessamad EA. Multiple and Bilateral Primary Brain Hydatid Cyst Dowling Technique is not always Appropriate (Case Report). International of Anatomy, Radiology and Surgery 2016;5:22-4.

12. Chatzidakis E, Zogopoulos P, Paleologos TS, Papageorgiou N. Surgi- cal Planning for the Treatment of a Patient with Multiple, Secondary, Intracranial Echinococcal Cysts. Surg J (NY) 2015;2:e7-10.

13. Saqui AE, Aggouri M, Benzagmout M, Chakour K, Faizchaoui ME. Hydatid cyst of the posterior fossa. Pan Afr Med J 2017;26:133.

14. Taghipour M, Saffarrian A, Ghaffarpasand F, Azarpira N. DumbbellShape Hydatid Cyst of Meckel Cave Extending to Cerebellopontine Angle and Middle Fossa; Surgical Technique and Outcome of Rare Case. World Neurosurg 2017;104:1049.e7-1049.e10. [CrossRef]

15. Altibi AM, Qarajeh RA, Belsuzarri TA, Maani W, Kanaan TM. Primary cerebral echinoccocosis in a child: Case report-Surgical technique, technical pitfalls, and video atlas. Surg Neurol Int 2016;7:S893-8. [CrossRef]

16. Pedrosa I, Saíz A, Arrazola J, Ferreirós J, Pedrosa CS. Hydatid disease: radiologic and pathologic features and complications. Radiographics 2000;20:795-817. [CrossRef]

17. Angın T, Çelebisoy M, Noyan Karatepe A, Gelal MF, Şirin HK. Cerebral Hydatid Cyst: A Case Report. Türk Nöroloji Dergisi 2014;20:87-90. [CrossRef]

18. Yurt A, Avci M, Selçuki M, Ozer F, Camlar M, Uçar K, et al. Multiple cerebral hydatid cysts. Report of a case with 24 pieces. Clin Neurol Neurosurg 2007;109:821-6. [CrossRef]

19. El-Shamam O, Amer T, El-Atta MA. Magnetic resonance imaging of simple and infected hydatid cysts of the brain. Magn Reson Imaging 2001;19:965-74. [CrossRef]

20. Beşkonakli E, Cayli S, Yalçinlar Y. Primary intracranial extradural hydatid cyst extending above and below the tentorium. Br J Neurosurg 1996;10:315-6. [CrossRef]

21. Bakhsh A, Siddiqui KMA, Taraif S. Primary hydatid cyst of pineal region of brain: A case report from Saudi Arabia. Asian J Neurosurg 2017;12:314-7.

22. Gangopadhyay AN, Srivastava P, Upadhyaya VD, Hasan Z. Is primary chemotherapy effective in large hydatid cyst of liver? J Indian Assoc Pediatr Surg 2009;14:40. [CrossRef]

23. Hajhouji F, Aniba K, Laghmari M, Lmejjati M, Ghannane H, Benali SA. Epilepsy: unusual presentation of cerebral hydatid disease in children. Pan Afr Med J 2016;25:58. doi: 10.11604/ pamj.2016.25.58.10706. [CrossRef]

24. Karakoc ZC, Kasımcan MO, Pipia AP, Tore G, Alberti A, Varcasia A. A life-threatening brainstem compression by cerebral echinococcus granulosus. Infez Med 2016;24:62-6.

\section{Primer Serebral Kist Hidatik Hastalığında Acil Cerrahi Tedavi: Olgu Sunumu ve Literatür Taraması}

Hidatik kistler, tüm intrakraniyal lezyonların \%3-4'ünü oluşturur. Tanı, tipik olarak sığır veya köpekle temas halinde olan bir yaşama ya da bir endemik alana seyahat geçmişine dayanan klinik şüpheye dayanır, serolojik testler ve görüntüleme ile teyit edilir. Literatürde serebral kist hidatik nedeni ile manyetik rezonans görüntüleme çekilemeden acil olarak opere edilen nadir olgu bildirilmiştir. Bu yazıda, 22 yaşında intrakraniyal basınç artışı bulgularıyla acil servise başvuran ve ani nörolojik kötüleşme ile acil operasyona alınan primer serebral kist hidatik olgusu literatür eşliğinde tartışıldı.

Anahtar Sözcükler: Acil; ekinokokkus; serebral kist hidatik. 